Supplement of Earth Surf. Dynam., 9, 505-517, 2021

https://doi.org/10.5194/esurf-9-505-2021-supplement

(C) Author(s) 2021. CC BY 4.0 License.

(c) (1)

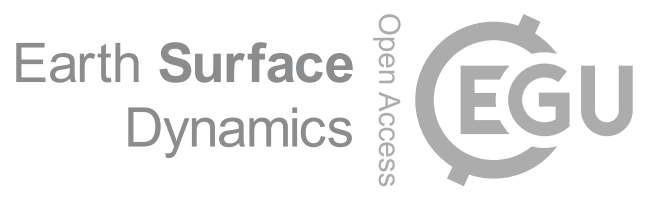

Supplement of

\title{
Locating rock slope failures along highways and understanding their physical processes using seismic signals
}

Jui-Ming Chang et al.

Correspondence to: Jui-Ming Chang (d04224006@ntu.edu.tw)

The copyright of individual parts of the supplement might differ from the article licence. 


\section{Contents of this file}

Section 1-Section 5

Tables S1 to S4

Figures $\mathrm{S} 1$ to $\mathrm{S} 9$

\section{Introduction}

The supplementary material includes five sections.

Section 1: Inventory of rock slope failure

Section 2: Spectrograms of RSFs

Section 3: Relationships between $\mathrm{M}_{\mathrm{L}}$ and $\mathrm{M}_{\mathrm{D}}$ in earthquakes and RSFs.

Section 4: Uncertainty in $\mathrm{A}_{0}$ and seismic attenuation

Section 5: Spectrogram features of rockfall.

\section{Supplementary References}




\section{Section 1 Inventory of rock slope failure}

Ten events have been selected in this research (Table S1). Six of them happened on the southern provincial highways (Event S1- Event S6). Event S1 to Event S5 are neighbors of the same road section. Based on the video and news (Table S2), Event S2 is the toppling event with visible crack before failure, Event S4 is a sliding event with massive material, and Event S5 is a big boulder blocked the road. Event S6 is on the different road sections whose material sliding from the steep slope. Three events were on the middle provincial highways (Event M1- Event M3). Event M1 is the only event that occurred during the typhoon period. Event M2 is a rockfall that blocked the road and damaged a car causing of death for a person. Event M3 is an event that happened on the steep slope. Event N1 is on the northern provincial highways, which is captured with face view by the video record showing the smallscale sliding at the beginning and large- scale detached/sliding in the following. After the events happen, the Directorate General of Highways (DGH) in Taiwan roughly estimates the volume except for two events, M1 and N1. The source area of Event M1 is mapped by the satellite image. With an assumed of $2 \mathrm{~m}$ of basal sliding depth, the volume of Event M1 is $164,000 \mathrm{~m}^{3}$. The volume of Event N1 is calculated by Sinotech Disaster Prevention Technology Research Center with two Digital Surface Models (DSM) which before and after the event. The volume in ten rock slope failures cross four orders from the smallest $108 \mathrm{~m}^{3}$ (Event $\mathrm{S} 5$; single boulder) to $164,000 \mathrm{~m}^{3}$ (Event M1 occurred during typhoon period). 
Table S1. Inventory of rock slope failures (grey background) and the calculated seismic parameters

\begin{tabular}{|c|c|c|c|c|c|c|c|c|c|c|c|c|}
\hline $\begin{array}{c}\text { Event } \\
\text { No. }\end{array}$ & $\begin{array}{c}\text { Date } \\
\text { (yyyy.mm.dd) }\end{array}$ & $\begin{array}{c}\text { Local } \\
\text { Time } \\
(\mathrm{UTC}+8)\end{array}$ & $\begin{array}{l}\text { Longitude } \\
\qquad\left({ }^{\circ} \mathrm{E}\right)\end{array}$ & $\begin{array}{l}\text { Latitude } \\
\qquad\left({ }^{\circ} \mathrm{N}\right)\end{array}$ & $\begin{array}{l}\text { Volume } \\
\qquad\left(\mathrm{m}^{3}\right)\end{array}$ & $\begin{array}{c}\mathrm{A}_{0} \\
(\mathrm{~cm} / \mathrm{s})\end{array}$ & $\mathrm{M}_{\mathrm{L}}$ & $\mathrm{M}_{\mathrm{D}}$ & $\mathrm{M}_{\mathrm{L}} / \mathrm{M}_{\mathrm{D}}$ & $\begin{array}{c}\text { Location } \\
\text { Quality } \\
\text { level }\end{array}$ & $\begin{array}{c}\text { Location } \\
\text { error } \\
(\mathrm{km})\end{array}$ & $\begin{array}{l}\text { Detected } \\
\text { station } \\
\text { number }\end{array}$ \\
\hline S1 & 2015.06 .05 & $10: 00$ & 121.027 & 23.176 & 2,000 & $1.60 \times 10^{-5}$ & $-0.09 \pm 0.52$ & $1.52 \pm 0.05$ & $-0,06$ & B & 1.55 & 2 \\
\hline S2 & 2015.07.27 & $16: 30$ & 121.039 & 23.177 & 2,000 & $3.40 \times 10^{-3}$ & $0.23 \pm 0.81$ & $1.36 \pm 0.20$ & 0,17 & $\mathrm{C}$ & 3.03 & 2 \\
\hline S3 & 2016.04 .22 & $10: 45$ & 121.032 & 23.173 & 5,000 & $4.00 \times 10^{-4}$ & $0.45 \pm 0.21$ & $1.38 \pm 0.11$ & 0,32 & B & 0.97 & 4 \\
\hline S4 & 2016.10 .04 & $15: 00$ & 121.028 & 23.176 & 21,000 & $4.03 \times 10^{-2}$ & $0.78 \pm 0.26$ & $2.30 \pm 0.13$ & 0,34 & A & 1.71 & 4 \\
\hline S5 & 2018.07 .18 & $12: 00$ & 121.042 & 23.177 & 108 & $6.05 \times 10^{-5}$ & $0.16 \pm 0.21$ & $1.10 \pm 0.06$ & 0,15 & $\mathrm{C}$ & 3.76 & 2 \\
\hline S6 & 2019.09 .12 & $12: 30$ & 121.112 & 23.138 & 2,000 & $3.35 \times 10^{-5}$ & $-0.31 \pm 0.92$ & $1.34 \pm 0.17$ & $-0,23$ & B & 1.55 & 4 \\
\hline M1 & 2015.08 .07 & - & 121.427 & 24.170 & $164,000 * 1$ & $1.20 \times 10^{-2}$ & $1.40 \pm 0.19$ & $2.91 \pm 0.11$ & 0,48 & $\mathrm{C}$ & 23.61 & 5 \\
\hline M2 & 2015.11 .27 & 08:30 & 121.520 & 24.177 & 400 & $9.80 \times 10^{-5}$ & $0.21 \pm 0.29$ & $2.45 \pm 0.12$ & 0,09 & $\mathrm{C}$ & 44.14 & 3 \\
\hline M3 & 2016.01 .27 & $22: 50$ & 121.551 & 24.171 & 13,000 & $6.61 \times 10^{-2}$ & $1.61 \pm 0.30$ & $1.95 \pm 0.22$ & 0,82 & $\mathrm{~A}$ & 3.19 & 5 \\
\hline N1 & 2019.07 .28 & 09:00 & 121.343 & 24.743 & $59,962 * 2$ & $2.86 \times 10^{-3}$ & $0.84 \pm 0.48$ & $2.03 \pm 0.24$ & 0,41 & B & 1.92 & 4 \\
\hline
\end{tabular}

${ }^{* 1}$ Calculated by satellite image with an assumption of $2 \mathrm{~m}$ depth.

${ }^{*}$ Calculated by Sinotech Disaster Prevention Technology Research Center with two DSMs which before and after the event. 
Table S2. Links of video or news of rock slope failures (last access: 2th Jun 2021)

\begin{tabular}{|c|c|c|}
\hline $\begin{array}{c}\text { Event } \\
\text { NO. }\end{array}$ & Links & Note \\
\hline S2 & $\begin{array}{l}\text { https://www.facebook.com/100000686768868/videos/ } \\
\text { 1029735617059321/ [Source1] } \\
\text { https://www.facebook.com/100009096117507/videos/ } \\
\text { 1479676335678889/[Source2] }\end{array}$ & $\begin{array}{l}\text { Detach: } 50 \text { secs } \\
\text { Impact: } 57 \text { secs }\end{array}$ \\
\hline S3 & http://www.touchmedia.tw/?p=398375 & \\
\hline S4 & $\begin{array}{l}\text { https://www.youtube.com/watch?v=jdQ8_G1u8Fs [Source1] } \\
\text { https://www.facebook.com/100001785733234/videos/ } \\
\text { 1096438083759039/[Source2] }\end{array}$ & $\begin{array}{l}\text { Massive mass } \\
\text { sliding: } 19 \text { secs }\end{array}$ \\
\hline S5 & https://www.youtube.com/watch?v=swHkDbWO5FU & \\
\hline S6 & https://news.tvbs.com.tw/politics/1199673 & \\
\hline M2 & $\begin{array}{l}\text { https://news.pts.org.tw/article/311411 [Source1] } \\
\text { https://www.youtube.com/watch?v=DYMKcqx5GZU [Source2] }\end{array}$ & \\
\hline M3 & $\begin{array}{l}\text { https://hualien.forest.gov.tw/all-news/0045072 [Source1] } \\
\text { https://news.ltn.com.tw/news/life/breakingnews/1587070 [Source]) }\end{array}$ & \\
\hline N1 & https://www.facebook.com/cloudfarm21/videos/669574973557488/ & $\begin{array}{l}\text { massive mass } \\
\text { sliding and impact: } \\
24 \text { secs }\end{array}$ \\
\hline
\end{tabular}




\section{Section 2 Spectrograms of RSFs}
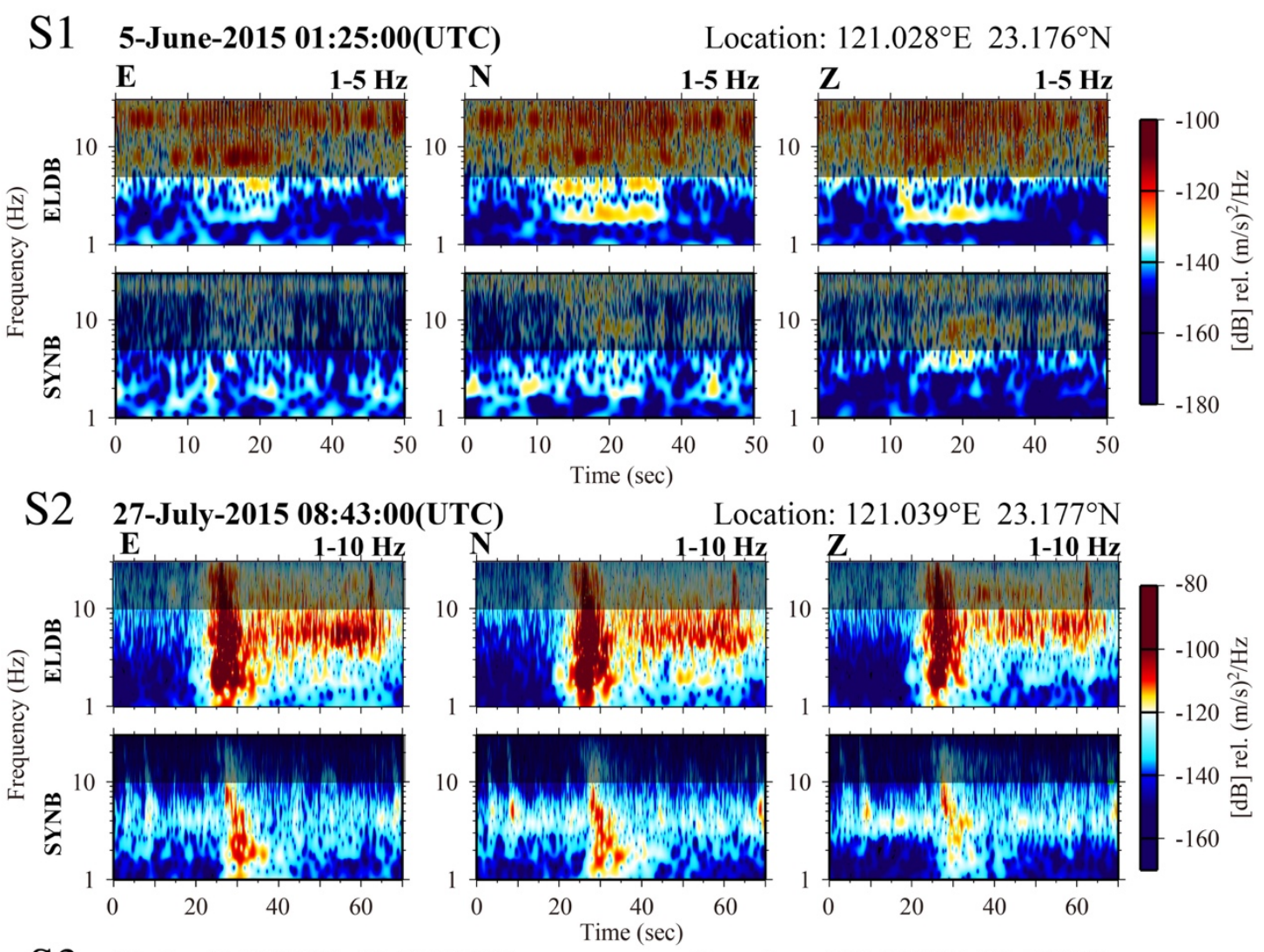

S3 22-April-2016 02:40:50(UTC)
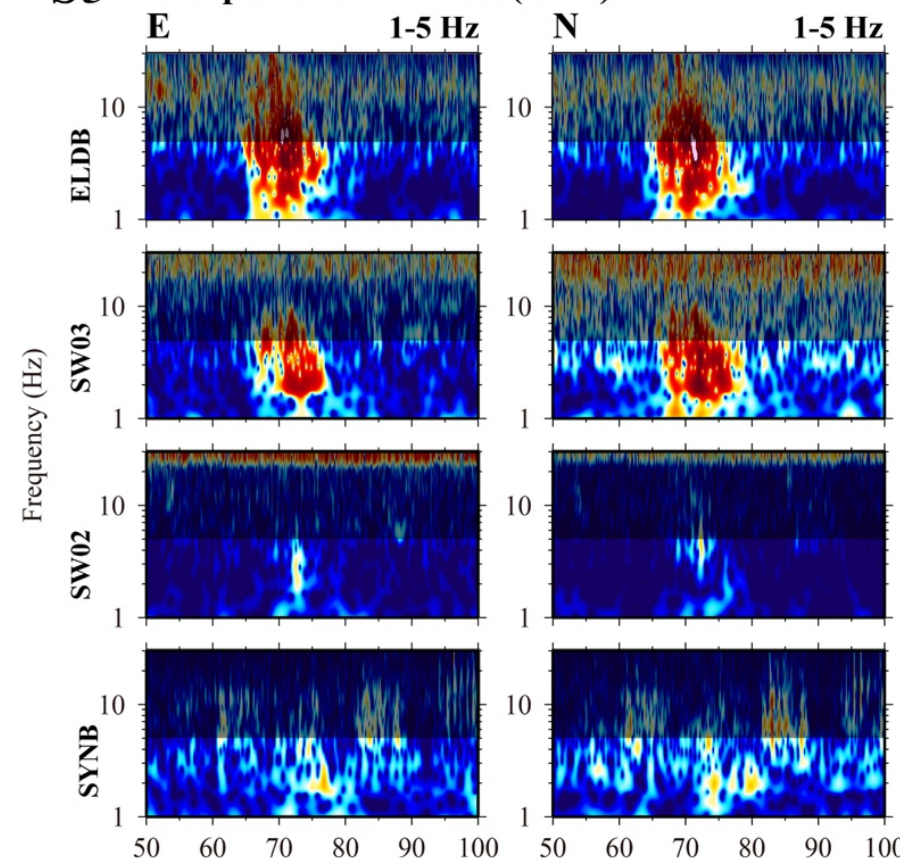

Location: $121.032^{\circ} \mathrm{E} 23.174^{\circ} \mathrm{N}$
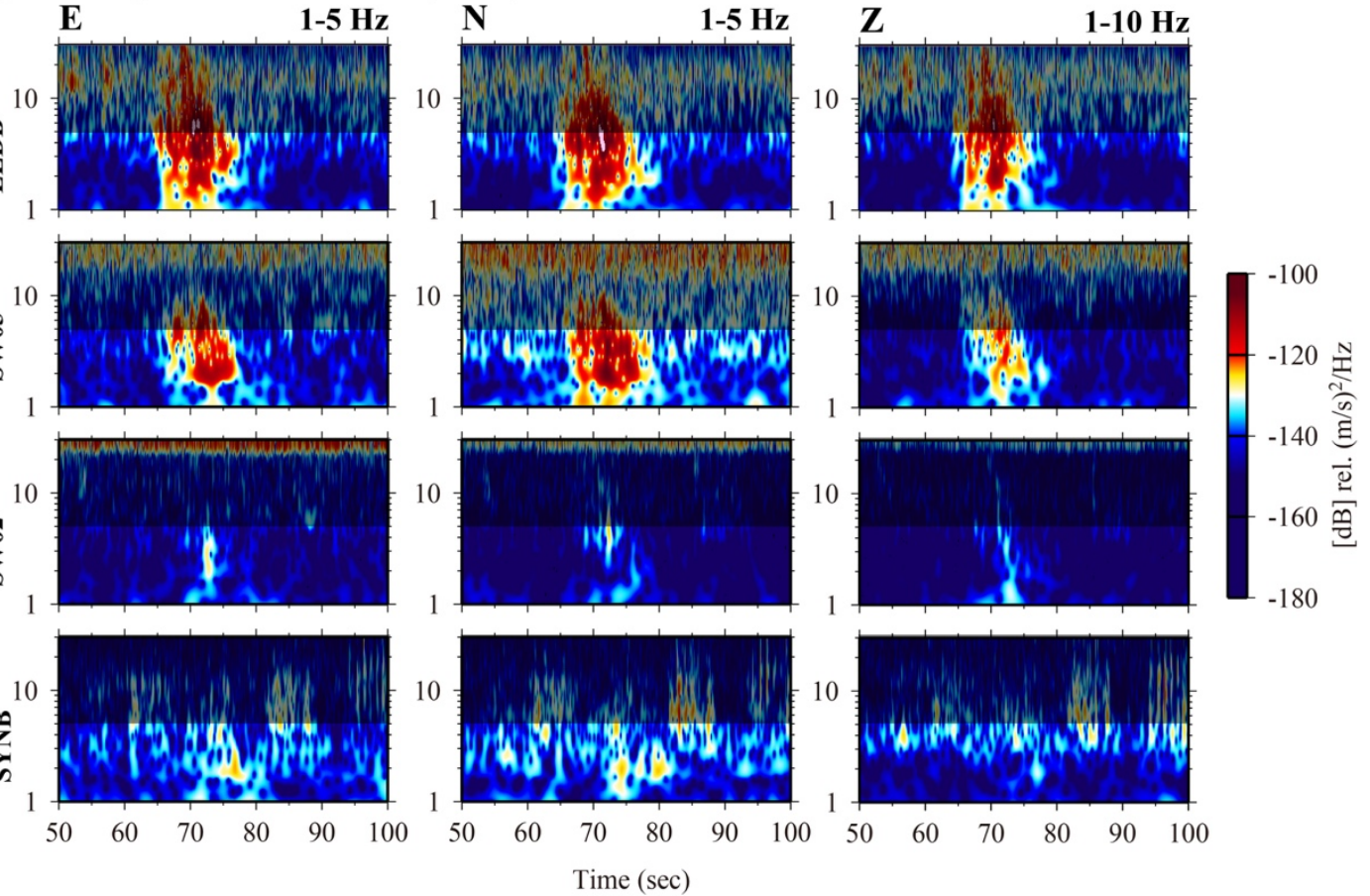

Figure S1. Spectrogram of three components of S1, S2 and S3 with filtering range. The information on the top shows the starting time form the $\mathrm{x}$-axis and source location. 


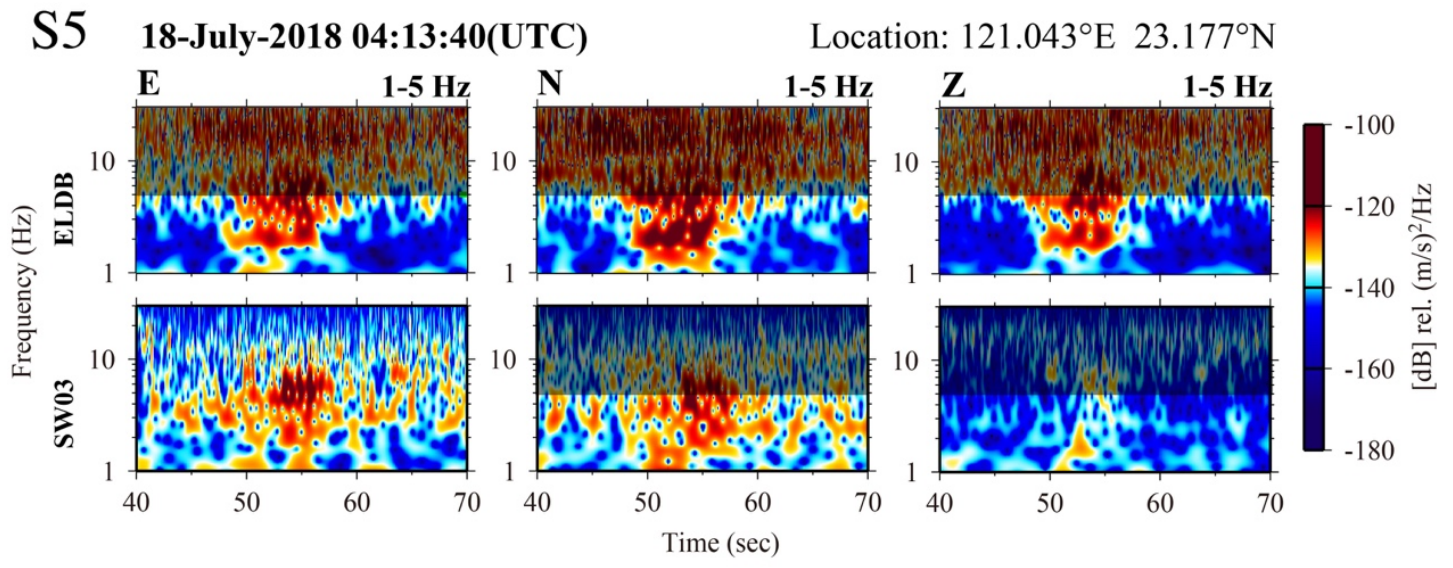

S6 12-September-2019 04:35:50(UTC) Location: $121.112^{\circ} \mathrm{E} 23.138^{\circ} \mathrm{N}$
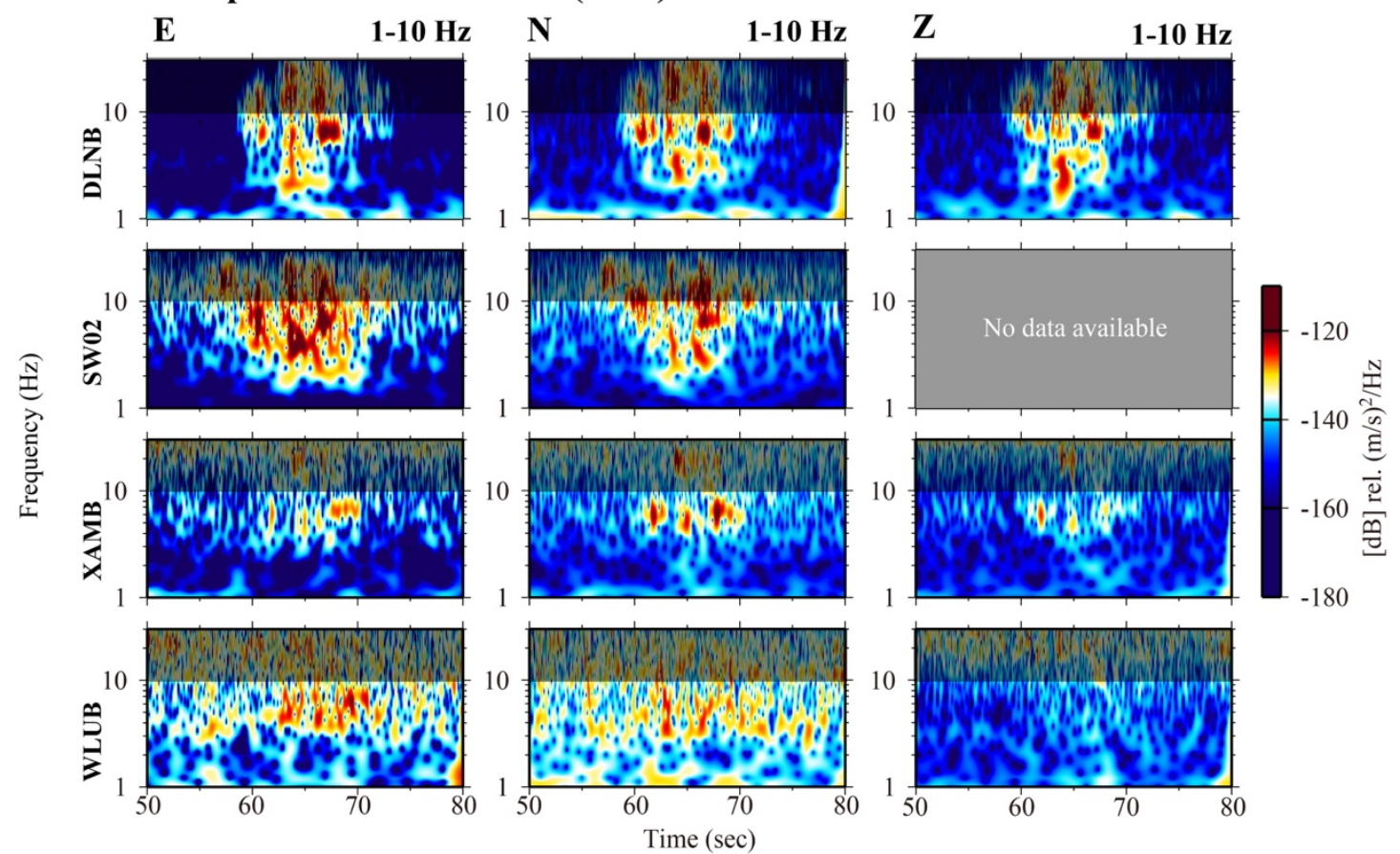

Figure S2. Spectrogram of three components of S5 and S6 with filtering range. The information on the top shows the starting time form the $\mathrm{x}$-axis and source location. 


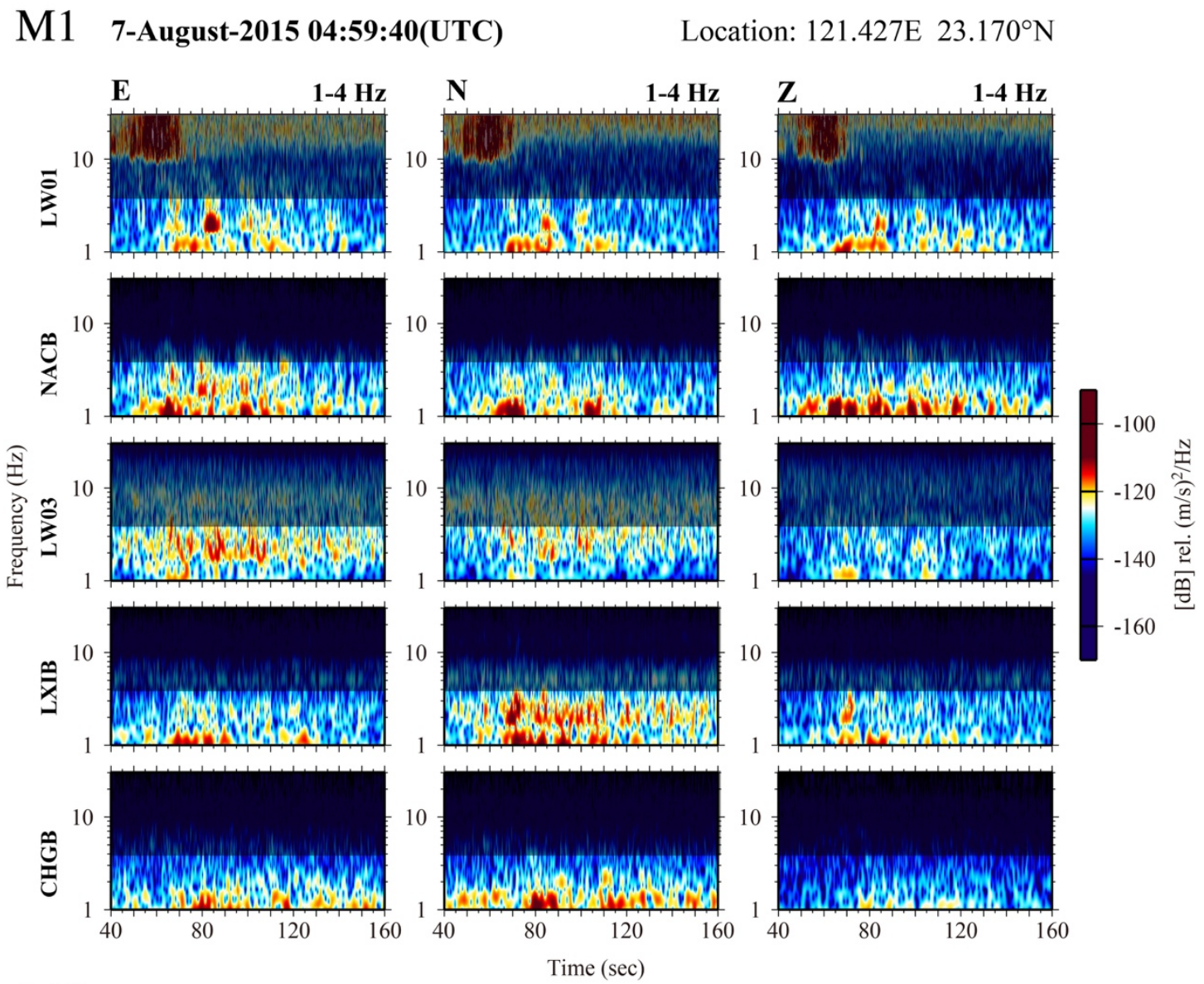

M2 27-November-2015 00:45:40(UTC) Location: $121.520^{\circ} \mathrm{E} 24.177^{\circ} \mathrm{N}$

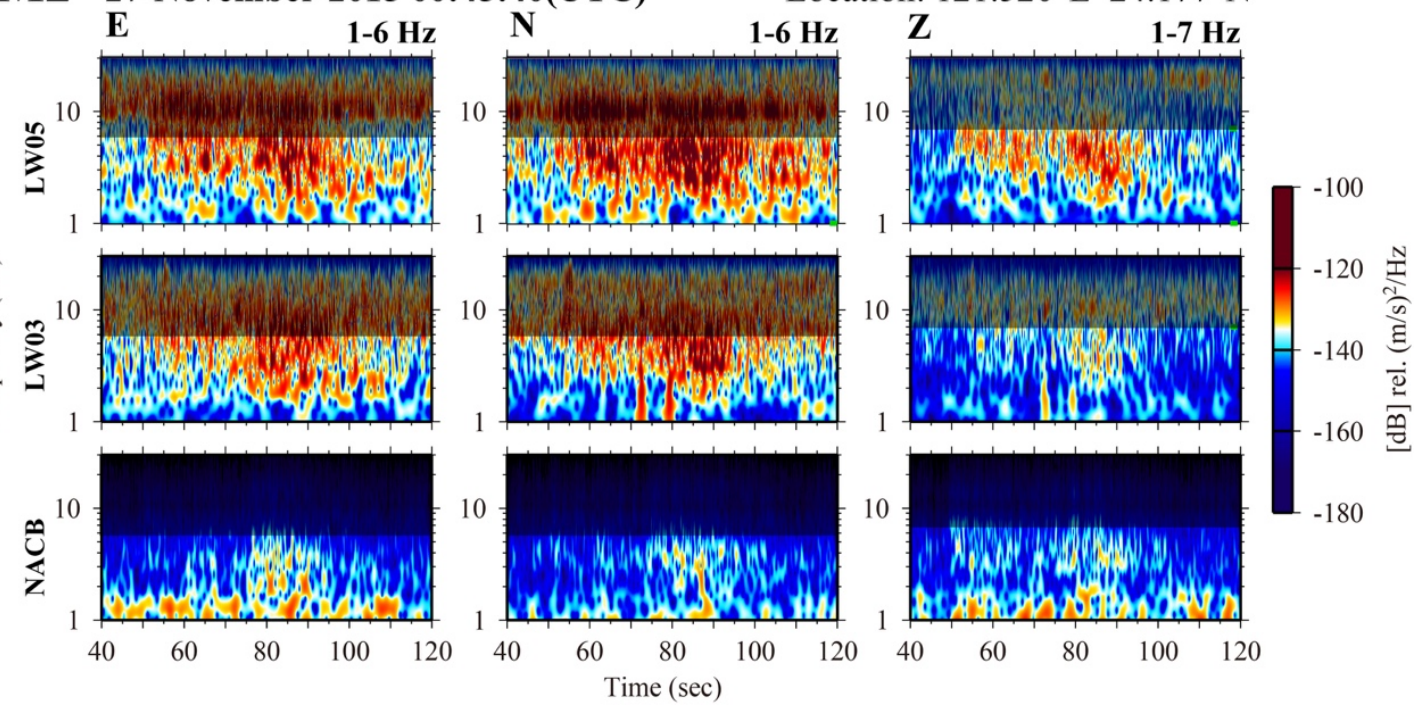

Figure S3. Spectrogram of three components of M1 and M2 with filtering range. The information on the top shows the starting time form the $\mathrm{x}$-axis and source location. 


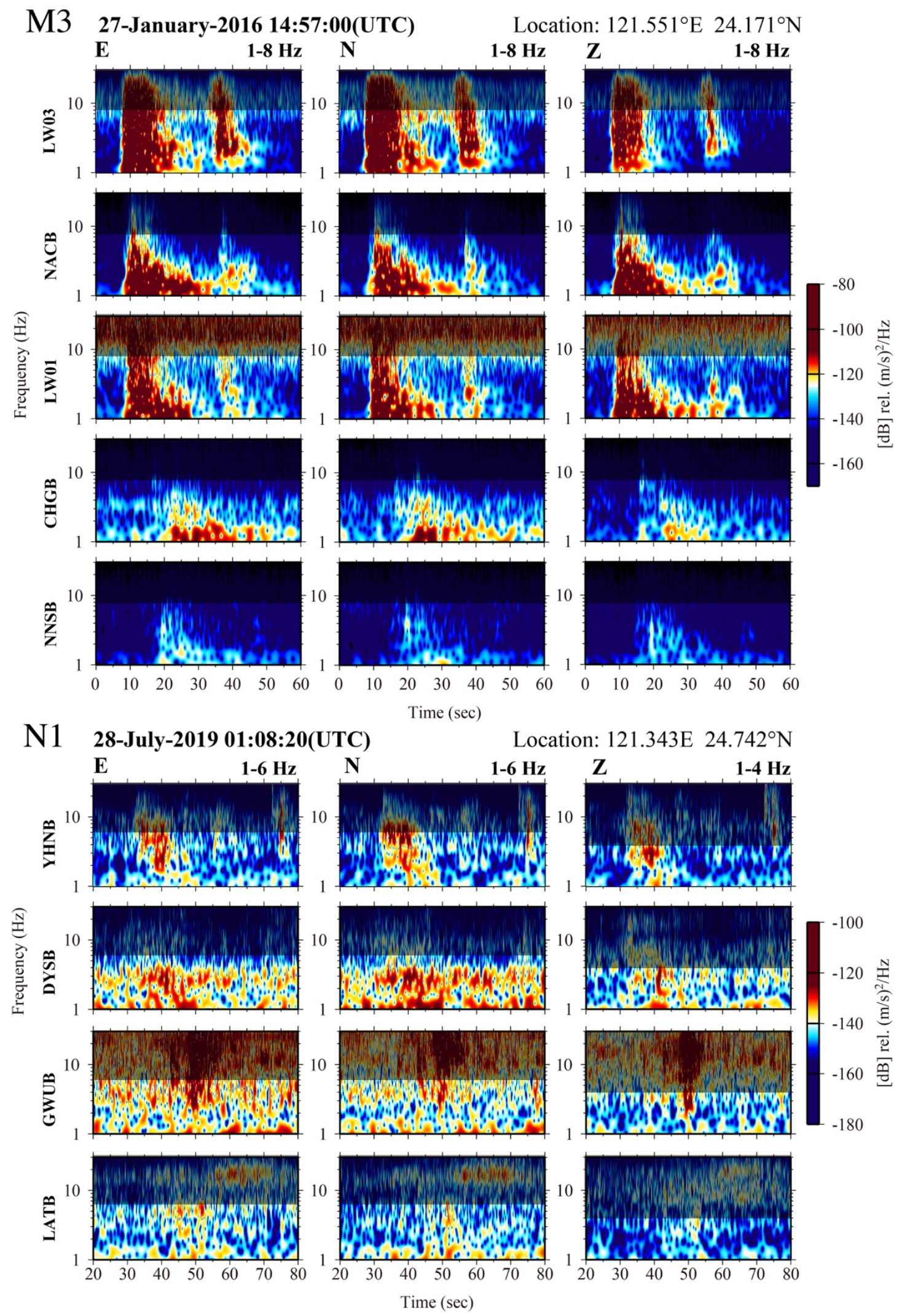

Figure S4. Spectrogram of three components of M3 and N1 with filtering range. The information on the top shows the starting time form the $\mathrm{x}$-axis and source location. 


\section{Section 3 Relationships between $M_{L}$ and $M_{D}$ for earthquakes and RSFs}

For a calculation of local magnitude $\left(\mathrm{M}_{\mathrm{L}}\right)$, the empirical magnitude equation proposed by Shin (1999) was used in this study. The $M_{L}$ is estimated based on the peak amplitude from the simulated Wood-Anderson seismic records. The duration magnitude $\left(\mathrm{M}_{\mathrm{D}}\right)$ can be computed based on the scaling relation of Lee et al. (1972) and whose duration is extracted from the spectrograms. For earthquakes (Table S3), the relationship between $M_{L}$ and $M_{D}$ is shown in below:

$$
M_{L}=1.21 M_{D}-0.44
$$

Whose slope closes to the empirical equation of regional earthquakes in Taiwan (Shin, 1999). In a case of RSFs, a regression line can be found and shown in below:

$$
M_{L}=0.67 M_{D}-0.71
$$

Since a lack of seismic signals with frequencies lower than $1 \mathrm{~Hz}$ was observed in our spectrogram analysis of RSFs, a resulting intercept value of -0.71 means the underestimation at the $\mathrm{M}_{\mathrm{L}}$ scale. Figure S5 shows a clear discrepancy in linear trend between the local earthquakes and the RSFs, which would be helpful to identify the different seismic sources.

Table S3. Ten earthquakes are used for $M_{L}, M_{D}$ and its' locating quality.

\begin{tabular}{|c|c|c|c|c|c|c|}
\hline Event & $\begin{array}{c}\text { Date } \\
\text { (yyyy.mm.dd) }\end{array}$ & $\begin{array}{c}\text { Time } \\
\text { (UTC) }\end{array}$ & $\mathrm{M}_{\mathrm{L}}$ & $\mathrm{M}_{\mathrm{D}}$ & $\mathrm{M}_{\mathrm{L}} / \mathrm{M}_{\mathrm{D}}$ & $\begin{array}{c}\text { Locating } \\
\text { Quality }\end{array}$ \\
\hline EQ1 & 2017.02 .24 & $00: 20: 12$ & $1.68 \pm 0.46$ & $1.68 \pm 0.34$ & 1,00 & $\mathrm{~B}$ \\
\hline EQ2 & 2017.05 .13 & $13: 12: 19$ & $1.74 \pm 0.49$ & $1.72 \pm 0.21$ & 1,01 & $\mathrm{~A}$ \\
\hline EQ3 & 2017.05 .18 & $03: 09: 08$ & $1.40 \pm 0.39$ & $1.63 \pm 0.12$ & 0,86 & $\mathrm{~B}$ \\
\hline EQ4 & 2017.05 .18 & $23: 34: 16$ & $1.72 \pm 0.41$ & $1.77 \pm 0.06$ & 0,97 & $\mathrm{~A}$ \\
\hline EQ5 & 2017.06 .15 & $23: 53: 35$ & $1.38 \pm 0.31$ & $1.46 \pm 0.16$ & 0,94 & $\mathrm{~B}$ \\
\hline EQ6 & 2017.06 .18 & $22: 47: 50$ & $2.11 \pm 0.52$ & $2.20 \pm 0.15$ & 0,96 & $\mathrm{~B}$ \\
\hline EQ7 & 2018.09 .27 & $15: 38: 18$ & $2.54 \pm 0.18$ & $2.46 \pm 0.06$ & 1,03 & $\mathrm{~A}$ \\
\hline EQ8 & 2018.09 .27 & $23: 32: 50$ & $1.78 \pm 0.10$ & $1.93 \pm 0.07$ & 0,92 & $\mathrm{~B}$ \\
\hline EQ9 & 2018.10 .02 & $11: 53: 47$ & $1.93 \pm 0.18$ & $1.96 \pm 0.09$ & 0,98 & $\mathrm{~B}$ \\
\hline EQ10 & 2019.10 .08 & $17: 36: 16$ & $2.83 \pm 0.24$ & $2.62 \pm 0.14$ & 1,08 & $\mathrm{~B}$ \\
\hline
\end{tabular}




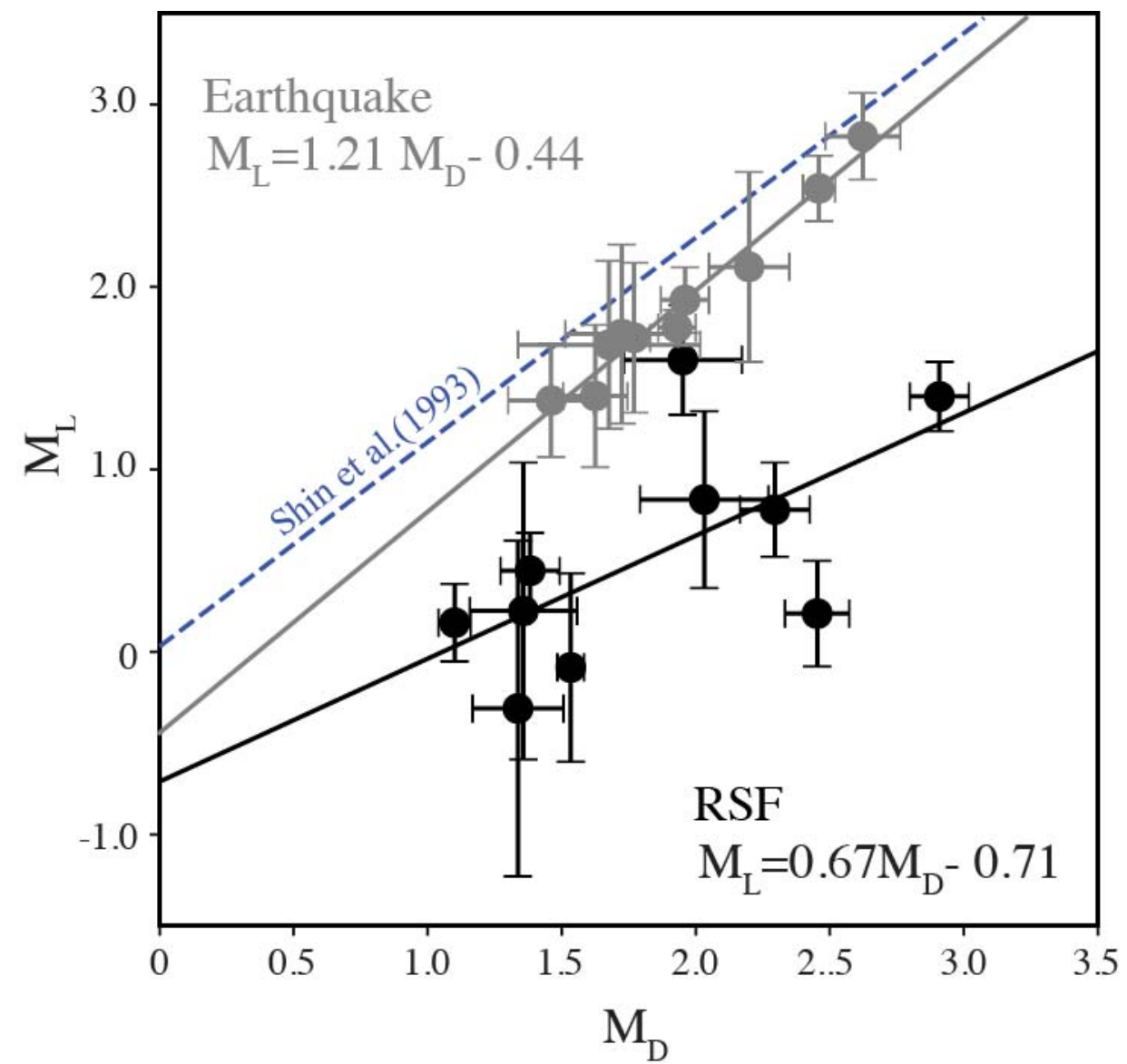

Figure S5. Relationship between $M_{L}$ and $M_{D}$ in earthquakes and rock slope failures. The black line is the rock slope failures with slope 0.67 and the grey line is the earthquakes with slope 1.21. The blue dash line is the empirical formula of an earthquake in Taiwan (Shin, 1999). 


\section{Section 4 Uncertainty in $A_{0}$ and seismic attenuation}

To explore the influence of imperfect event location on $\mathrm{A}_{0}$, we focus on results of ASL from the Events S4 and M3 with the quality level A. For a given $i$-th grid point, ASL method can provide the seismic amplitude $\mathrm{A}_{0 i}$ and $\alpha_{i}$ based on the best fitting of amplitude decay curve. We define the location error by the distance between the true location and a tried $i$-th grid point. The seismic amplitude at the true location is $\mathrm{A}_{0 t}$. Then, the error of $\mathrm{A}_{0}(E O A)$ for a specific location error $(e)$ can be defined as:

$$
E O A(e)=\frac{1}{n_{e}} \sum\left|\frac{A_{0 t}-A_{0 i}}{A_{0 t}}\right| \times 100 \%
$$

Where $\mathrm{n}_{\mathrm{e}}$ is total number of grid points for a specific e. $\mathrm{A}_{0 i e}$ is seismic amplitude at the $i$-th grid point related to the location error $(e)$. Figure S6 shows the $E O A$ as function of $e$ value for two events, and horizontal and vertical envelopes. Obviously, EOA of Event S4 increase more rapidly than the Event M3, meaning the $\mathrm{A}_{0}$-value in the Sinwulyu catchment is more sensitive to location error than the Liwu catchment. Notably, EOA of Event S4 reaches $90 \%$ when the $e$ is $3 \mathrm{~km}$. Thus, in the cases of (1) events with quality level $\mathrm{C},(2)$ the number of used station in location procedure less than 3, or (3) the best resulting location derived from CC method cannot offer the $A_{0}$ due to negative $\alpha$, then we correct the $A_{0}$-value with the peak amplitude recorded at the nearest station if a distance between the nearest station and the true location is less than $3 \mathrm{~km}$. For other events (Events M3, S4, N1, and S3) with quality levels $\mathrm{A}$ or $\mathrm{B}$, we simply utilize the $\mathrm{A}_{0}$-value at the best location determined by GeoLoc scheme. Event M1 with a large location error is not included in the regression analysis. Totally, 9 observations of $\mathrm{A}_{0}$-value were used to establish a power scaling of the volume and $\mathrm{A}_{0}$-value.

The $\alpha$ is also different from the Event M3 and S4 (Table S4). The result satisfied the criteria of location error we set are M3-H, M3-Z, S4-H, S4-Z, and S3-H. The average $\alpha$ for the Sinwulyu catchment average is $0.000274 \mathrm{~m}^{-1}$. It is around an order of magnitude higher than that in the Liwu catchment, which indicates more substantial attenuation of seismic signals produced by events in the Sinwulyu catchment. Event S3 and S4 locate around the boundary of Pre-Tertiary metamorphic and Pilushan Formation (Figure S7) where is composed of the discontinuities and fractured bedrock (Crespi et al., 1996) can explain above observations. 
Based on the attenuation characteristics in the Sinwulyu catchment, we further investigated the relation between the peak amplitude and epicentral distance for the ten earthquakes and RSFs. The result indicates that the seismic energy of rock slope failures cannot propagate over $10 \mathrm{~km}$, supporting the high $\alpha$ value in the Sinwulyu catchment again. The fractured bedrock area's unique feature can be an additional indicator to classify the earthquakes and rock slope failures in real-time monitoring.

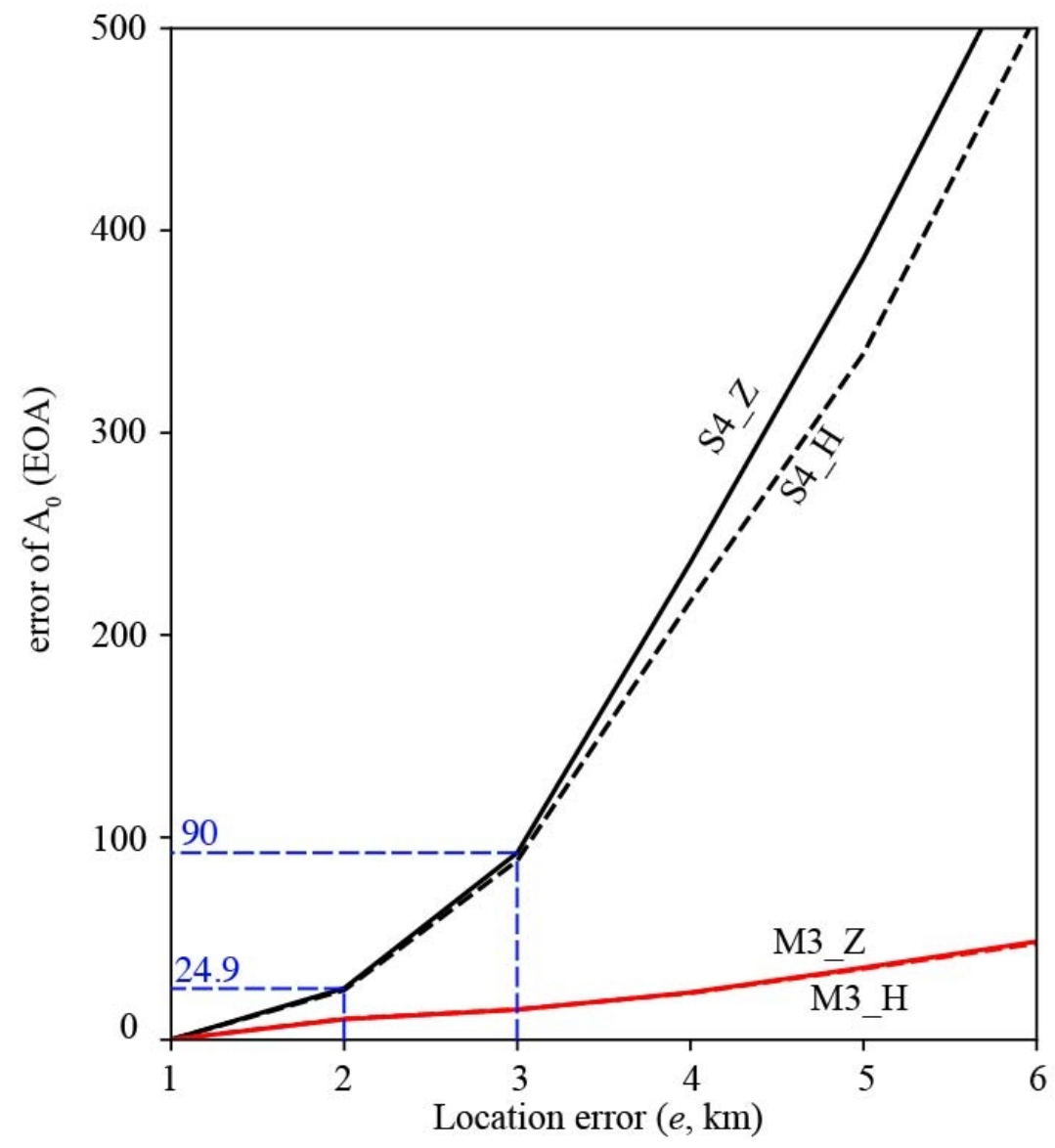

Figure S6. Uncertainty estimation of $\mathbf{A}_{0}$. The relationship between the location error( $e$ ) from true location to a tried $i$-th grid point and error of $\mathrm{A}_{0}$. Two best results of ASL is applied to retrieve the uncertainty.

Table S4. $\alpha$ in five different results of three events

\begin{tabular}{|c|c|c|}
\hline Event & Component & $\alpha(1 / \mathrm{m})$ \\
\hline M3 & $\mathrm{H}$ & 0.0000469 \\
\hline M3 & $\mathrm{Z}$ & 0.0000454 \\
\hline S3 & $\mathrm{H}$ & 0.0002715 \\
\hline S4 & $\mathrm{H}$ & 0.0002684 \\
\hline S4 & $\mathrm{Z}$ & 0.0002826 \\
\hline
\end{tabular}




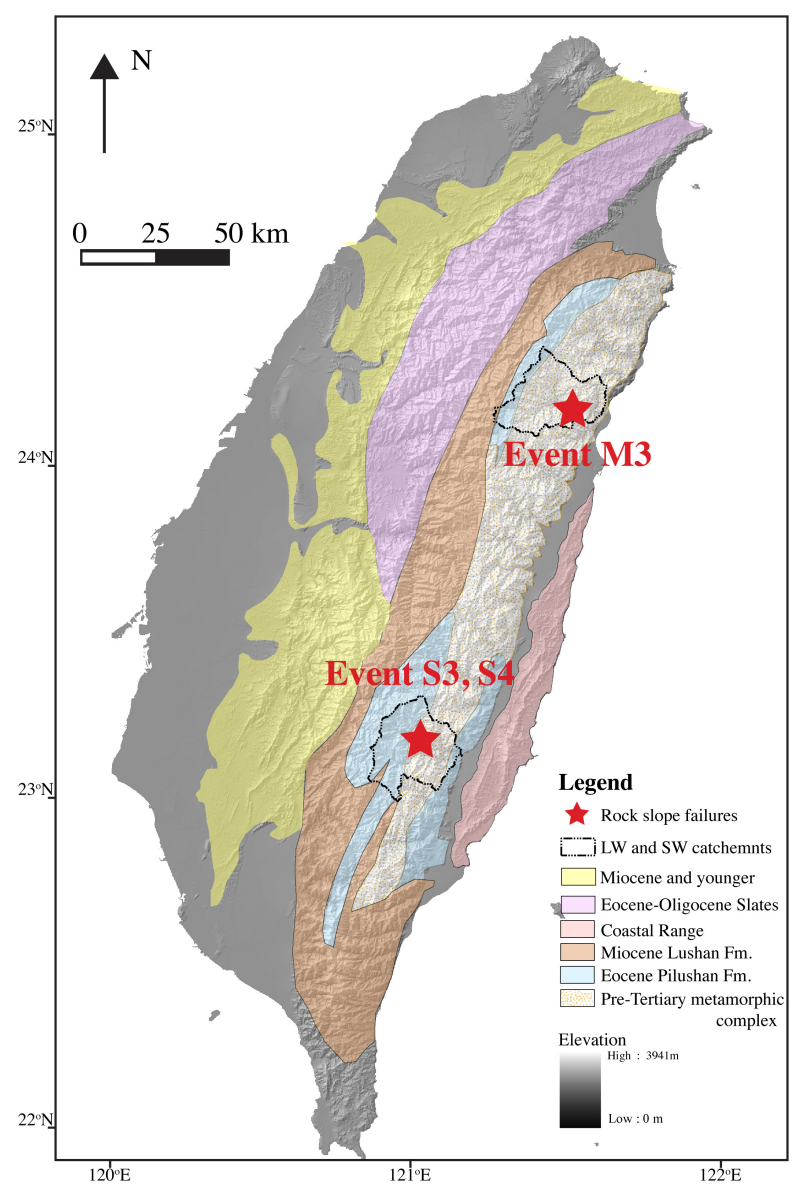

Figure S7. Geological map of Taiwan and Location of Events M3, S3 and S4. The geological map of Taiwan modified from Willett et al. (2003). The data of Digital Elevation Model (DEM) of Taiwan is from Government Open Data Platform, Taiwan.

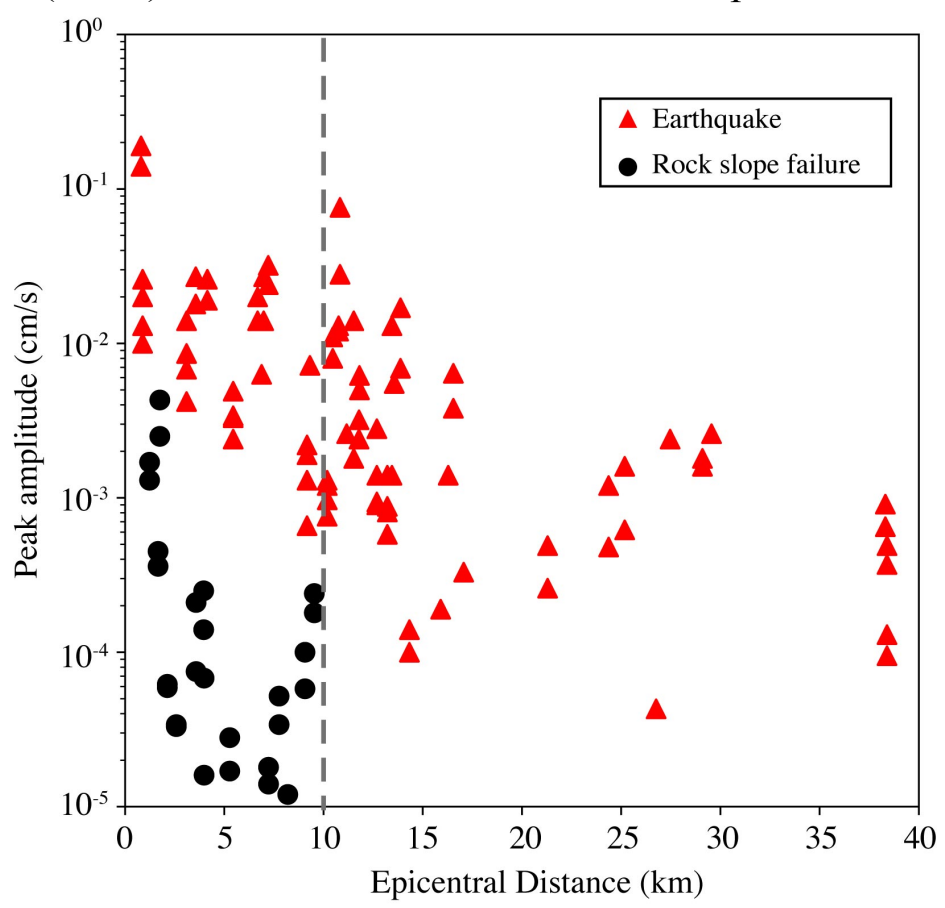

Figure S8. The epicentral distance and peak amplitude in each station for earthquakes and rock slope failures(S1-S6). The grey dash line is a threshold of seismic wave propagation distance for six RSFs in the Sinwulyu catchment. 


\section{Section 5 Spectrogram features of rockfall}

The physical process of rockfall is connected to seismic signals. A rockfall contains physical processes such as detachment, falling, impact, propagation, and fragmentation (Hungr et al., 2013). They compose the primary failure and many subevents with time delay. The seismic signals can precisely correspond to their process and the signals sometimes repeat within several minutes with many peaks due to rock interacting with the substrate (Tonnellier et al., 2013). A rock slide experiment from Hilbert et al. (2017) can see the feature. They push a rock boulder of $209 \mathrm{~kg}$ from the top of the slope. The significant impact shows the pulse feature in the seismic signals and their spectrograms. In the real cases of Yosemite Village, the feature is the same display (Zimmer et al., 2012). However, for a rockfall with the propagation of longer distance and fragmentation process, the feature of seismic signals is slightly different. Le Roy et al. (2019) and Dietze et al. (2017) deployed seismic networks in high risk slope and show that the propagation and fragmentation process contributes a long tail of seismic signals. The moving distance dominates the signal duration. The feature is similar to IRM phase in this research which links to the multiples rocks interacting with slope, propagation and fragmentation.

For Event S5 and M2, no video can support the physical process of rock slope failures; Nevertheless, the news captures the field photo. The Event S5 is a big boulder that blocked the road. The Event M2 composes several rock boulders distributing on the road. Further, the size of the Event S5 is more massive than Event M2. The spectrogram of these two events contains the same feature, pulse in their spectrograms (Figure S9). The spectrogram feature of Event S5 is similar to the rock slide experiment (Hilbert et al., 2017), and Event M2 is the peaks repeat themselves within 55 seconds. Further, Huang et al. (2007) uses a different rock size and do the free fall test. They found that a more prominent boulder inherits a smaller frequency band. It also shows in the S5 and M2. The frequency band of Event S5 is lower than Event M2. So, the physical process of the events belongs to rockfall. 


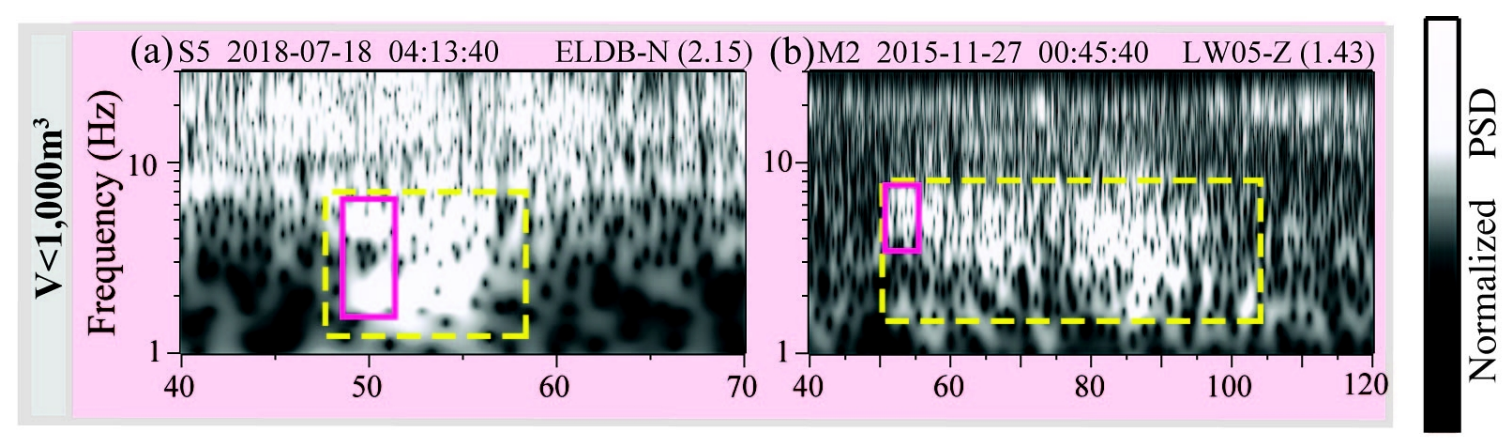

Time(secs)

Figure S9. Spectrogram of two rock fall events. The top left corner is the event number and the starting time of the $\mathrm{x}$-axis. The top right corner is the station name with the component and the epicentral distance $(\mathrm{km})$. The yellow dashed rectangle is the duration of two events. The pink lines are the pulse features of impaction processes. 


\section{Supplementary References}

Crespi, J.M., Chan, Y.C. and Swaim, M.S.: Synorogenic extension andexhumation of the Taiwan hinterland, Geology, 24, 247 -250. https://doi.org/10.1130/00917613(1996)024\%3C0247:SEAEOT\%3E2.3.CO;2, 1996.

Dietze, M., Turowski, J.M., Cook, K.L. and Hovius, N.: Spatiotemporal patterns, triggers and anatomies of seismically detected rockfalls. Earth Surf. Dynam., 5, 757-779. https://doi.org/10.5194/esurf-5-757-2017, 2017.

Hibert, C., Malet, J.P., Bourrier, F., Provost, F., Berger, F. and Bornemann, P., et al.: Single-block rockfall dynamics inferred from seismic signal analysis. Earth Surf. Dynam., 5, 283-292. https://doi.org/10.5194/esurf-5-283-2017, 2017.

Huang, C.J., Yin, H.Y., Chen, C.Y., Yeh, C.H. and Wang, C.L.: Ground vibrations produced by rock motions and debris flows, J. Geophys. Res. Earth Surf.,112, F02014, https://doi.org/10.1029/2005JF000437, 2007.

Hungr, O., Leroueil, S. and Picarelli, L.: The Varnes classification of landslide types, an update. Landslides, 11 (2), 167-194. https://doi.org/10.1007/s10346-0130436-y, 2013.

Manconi, A., Picozzi, M., Coviello, V., de Santis, F. and Elia, L.: Real time detection, location, and characterization of rockslides using broadband regional seismic networks. Geophys. Res. Lett., 43, 6960-6967, https://doi.org/10.1002/2016GL069572, 2016.

Lee, W.H., Bennett, R.E. and Meagher, K.L.: A Method of Estimating Magnitude of Local Earthquakes from Signal Duration. U.S. Geological Survey Open-File Report, 1972.

Le Roy, G.Le., Helmstetter, A., Amitrano, D., Guyoton, F. and Roux-Mallouf, R.Le.: Seismic analysis of the detachment and impact phases of a rockfall and application for estimating rockfall volume and free-fall height. J. Geophys. Res. Earth Surf., 124, 2602-2622, https://doi.org/10.1029/2019JF004999, 2019.

Shin, T.C.:The Calculation of Local Magnitude from the simulated Wood-Anderson Seismograms of the Short-Period Seismograms in the Taiwan Area. Terr. Atmos. Ocean. Sci., 4, 155-170. https://doi.org/10.3319/TAO.1993.4.2.155(T), 1993.

Tonnellier, A., Helmstetter, A., Malet, J.P, Schmittbuhl, J., Corsini, A. and Joswig, M.: Seismic monitoring of soft-rock landslide: the Super-Sauze and Valoria case studies. Geophys. J. Int., 193, 1515-1536. https://doi.org/10.1093/gji/ggt039, 2013.

Walter, F., Burtin, A., McArdell, B. W., Hovius, N., Weder, B. and Turowski, J. M.: Testing seismic amplitude source location for fast debris-flow detection at Illgraben, Switzerland. Nat. Hazards Earth Syst. Sci., 17(6), 939-955, https://doi.org/10.5194/nhess-17-939-2017, 2017.

Willett, S.D., Fisher, D., Fuller, C., Yeh, E.C. and Lu, C.Y.: Erosion rates and orogenic wedge kinematics in Taiwan inferred from apatite fission track thermochronometry, Geology, 31, 945-948, 2003. 